慶應義塾大学学術情報リポジトリ

Keio Associated Repository of Academic resouces

\begin{tabular}{|c|l|}
\hline Title & $\begin{array}{l}\text { Attenuation of platelet activating factor (PAF)-induced stimulation of rabbit platelet GTPase by } \\
\text { phorbol ester, dibutyryl cAMP and desensitization : concomitant effects on PAF receptor binding } \\
\text { characteristics }\end{array}$ \\
\hline Sub Title & \multicolumn{1}{|c|}{} \\
\hline Author & $\begin{array}{l}\text { 本間, 浩(Honma, Hiroshi) } \\
\text { Hanahan, Donald J. }\end{array}$ \\
\hline Publisher & 共立薬科大学 \\
\hline Publication year & 1988 \\
\hline Jtitle & $\begin{array}{l}\text { 共立薬科大学研究年報 (The annual report of the Kyoritsu College of } \\
\text { Pharmacy). No.33 (1988. ),p.141-141 }\end{array}$ \\
\hline JaLC DOI & \\
\hline Abstract & \\
\hline Notes & 抄録 \\
\hline Genre & Technical Report \\
\hline URL & https://koara.lib.keio.ac.jp/xoonips/modules/xoonips/detail.php?koara_id=AN00062898-0000003 \\
3-0141
\end{tabular}

慶應義塾大学学術情報リポジトリ(KOARA)に掲載されているコンテンツの著作権は、それぞれの著作者、学会または出版社/発行者に帰属し、その権利は著作権法によって 保護されています。引用にあたっては、著作権法を遵守してご利用ください。

The copyrights of content available on the KeiO Associated Repository of Academic resources (KOARA) belong to the respective authors, academic societies, or publishers/issuers, and these rights are protected by the Japanese Copyright Act. When quoting the content, please follow the Japanese copyright act. 


\title{
Attenuation of Platelet Activating Factor (PAF)-induced Stimulation of Rabbit Platelet GTPase by Phorbol Ester, Dibutyryl cAMP and Desensitization: Concomitant Effects on PAF Receptor Binding Characteristics*
}

\author{
Hiroshi Homma and Donald J. Hanahan** \\ 本間 浩, Donald J. Hanahan**
}

The GTPase activities of rabbit platelet membrane were stimulated by platelet activating factor (PAF) in a receptor-mediated manner. The activities of the GTPase were investigated in the platelets which had been pretreated with tetradecanoyl phorbol acetate (TPA), dibutyryl cAMP, and PAF. The specific binding of PAF to intact platelet cells was also determined in these treated cells. In platelets which had been pretreated with PAF and then specifically desensitized to PAF, higher concentrations were required for stimulation of the receptor-coupled GTPase. In addition the extent of stimulation of the GTPase by PAF was also decreased. By contrast thrombin stimulation of GTPase activity was unaffected by this process. In platelets pretreated with high levels of dibutyryl cAMP $(4 \mathrm{mM})$, the specific binding of PAF was reduced to nearly, $50 \%$ of the control. Although this specific binding apparently was not inhibited by lower concentrations of dibutyryl cAMP ( $2 \mathrm{mM})$, PAF could stimulated the receptor-coupled GTPase only to a much lower extent in these treated cells. TPA had virtually no effect on PAF specific binding. However, higher concentrations were needed for stimulation of the GTPase. On the other hand, the extent of PAF stimulation of the GTPase was not altered. Interestingly in the TPAtreated platelet membrane, thrombin stimulated GTPase activity to a higher level than that in untreated platelet membrane. Thus, TPA, dibutyryl cAMP, and desensitization affected the PAF receptor binding and the receptor-coupled GTPase activities in a characteristic fashion. The molecular mechanisms of these effects are discussed.

* 本報告は Arch. Biochem. Biophys., 262, 32-39（1988）に発表.

** The University of Texas Health Science Center 